\title{
Properties of $\mathrm{ZrO}_{2}-\mathrm{Al}_{2} \mathrm{O}_{3}$ ceramics produced from different powder mixtures of zirconia and aluminum hydroxide
}

ILIYA ZHUKOV - Tomsk State University, Institute of Strength Physics and Materials Science SB RAS

SvetLanA P. BUYAKOVA - Tomsk State University, Institute of Strength Physics and Materials Science SB RAS SERGEI S. KULKOV - Tomsk State University, Institute of Strength Physics and Materials Science SB RAS Érkezett: 2016. 06. 20. - Received: 20. 06. 2016. - http://dx.doi.org/10.14382/epitoanyag-jsbcm.2016.13

\section{Abstract}

Porous $\mathrm{ZrO}_{2}-\mathrm{Al}_{2} \mathrm{O}_{3}$ ceramics produced from powder mixtures of zirconia and aluminum hydroxide obtained by different methods is studied. The paper presents the data on the structure, phase composition, crystal structure and strength of the studied ceramics. It is found that the strength of the sintered $\mathrm{ZrO}_{2}-\mathrm{Al}_{2} \mathrm{O}_{3}$ composites depends on the type of aluminum hydroxide used in the initial powder mixture. The pore size of the produced ceramics is shown to depend on sintering temperature. The crystallite size is determined at which the studied composites become solid.

Keywords: $\mathrm{ZrO}_{2}-\mathrm{Al}_{2} \mathrm{O}_{3}$ composites, sintering, strength, crystallite size

\section{Introduction}

Composite materials on the basis of $\mathrm{ZrO}_{2}-\mathrm{Al}_{2} \mathrm{O}_{3}$ have high strength, fracture toughness, corrosion and heat resistance. These properties allow the $\mathrm{ZrO}_{2}-\mathrm{Al}_{2} \mathrm{O}_{3}$ ceramics to be used as materials for the production of bio-implants, catalyst carriers, membranes and filters $[1,2]$.

Porosity of the material and its porous structure determine the working characteristics of the ceramic products. Typically, required porosity and pore morphology in ceramic materials is attained by introducing and subsequent removal (by annealing) of an organic pore former. However, despite simplicity and accessibility, this method has a drawback, which is the presence of combustion products of the pore former (carbon and its compounds) in the porous material after annealing. The presence of compounds in the bulk of the material is inadmissible for bio-implants, catalyst carriers and filters. In order to avoid the presence of foreign compounds in a porous material, the required porosity is achieved through methods that imply the decomposition of powder mixture constituents into simpler compounds during sintering accompanied by gas release. An example of this kind of reaction is the decomposition of hydroxides to oxides. Although this method of producing porous materials has long been known, the literature provides no information on the structure and properties of ceramics produced by the given method. The aim of this paper is to study how the structure and properties of zirconia and aluminum hydroxide powders influence the structure and properties of $\mathrm{ZrO}_{2}-\mathrm{Al}_{2} \mathrm{O}_{3}$ ceramics. 


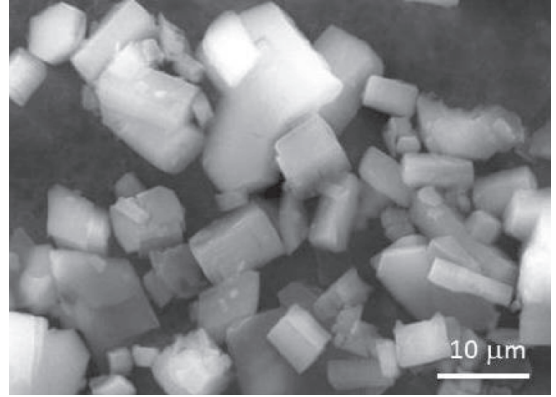

a)

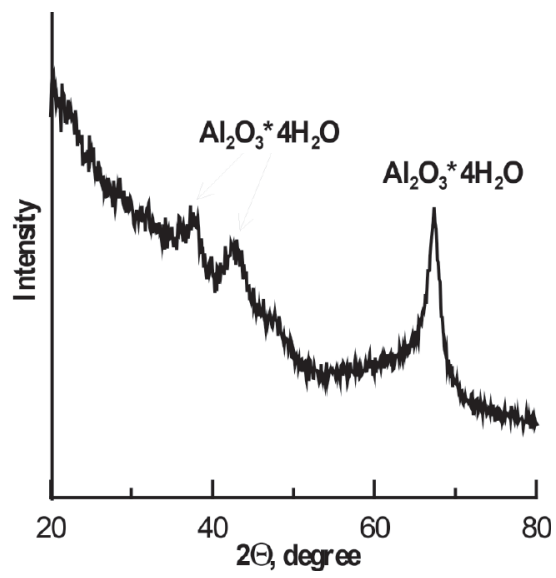

b)

Fig. 1. SEM image of the aluminum hydroxide powder produced by aluminate solution decomposition (a), and X-ray diffraction pattern of this powder (b)

1. ábra Aluminátoldat lebontásával szintetizált alumínium hidroxid por elektronmikroszkópos képe (a) és röntgendiffraktogramja (b)

\section{Results and discussion}

\subsection{Powders}

Examination of zirconia powders shows that the powder produced by chemical deposition ( $\mathrm{CD}$ powder) consists of individual polycrystalline aggregates, and the powder produced by plasma chemical synthesis (PCS powder) consists of spherical particles and their aggregates. The average particle size, specific surface area, the content of the tetragonal zirconia phase, the size of the coherent diffracting domains of the tetragonal zirconia modification, microdistortion, and lattice parameters of the powders are given in Table 1.

Fig. 1.a shows the SEM image of the aluminum hydroxide powder produced by aluminate solution decomposition; the average powder particle size is $2.6 \mu \mathrm{m}$. The X-ray diffraction pattern of this powder has only three most intensive reflections from hydrated alumina $\mathrm{Al}_{2} \mathrm{O}_{3} \times 4 \mathrm{H}_{2} \mathrm{O}$ (Fig. 1.b).

The high background at small diffraction angles suggests that the major part of the powder was in the X-ray amorphous state.

The aluminum hydroxide powder produced by hydrolysis of aluminum powder consists of spherical aggregates formed by individual particles (Fig. 2.a); the average particle size is $1.5 \mu \mathrm{m}$. According to X-ray analysis data, the powder has only one phase corresponding to bayerite $\mathrm{Al}(\mathrm{OH})_{3}$ (Fig. 2.b).

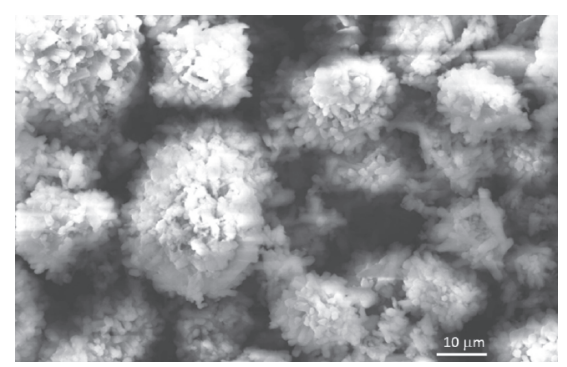

a)

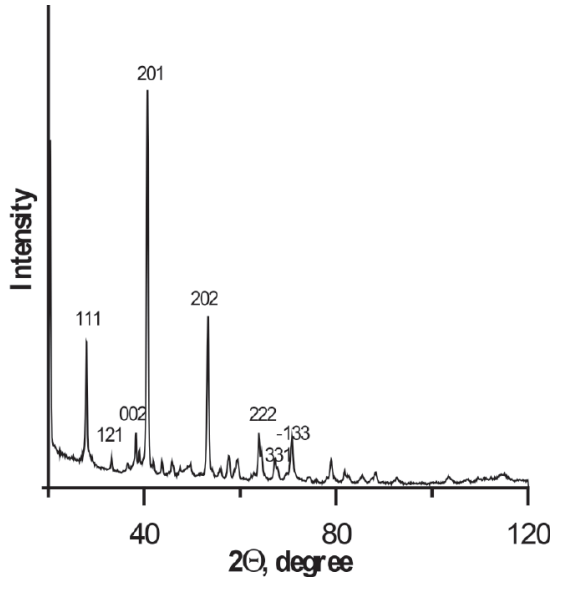

b)

Fig. 2. SEM image of the aluminum hydroxide powder produced by hydrolysis of aluminum (a), and X-ray diffraction pattern of this powder $(b)$

2. ábra Alumínium hidrolizisével szintetizált alumínium hidroxid por elektronmikroszkópos képe (a) és röntgendiffraktogramja (b)

\subsection{Sintered $\mathrm{ZrO}_{2}-\mathrm{Al}_{2} \mathrm{O}_{3}$ ceramics}

The structure of the obtained composite materials is represented by light and dark regions and by pores. According to elemental analysis data, the light regions correspond to zirconia, and the dark regions correspond to alumina (Fig. 3.a). Analysis of the influence of the aluminum hydroxide volume fraction in the initial powder mixture on the average pore size of the composites shows that the dependences are different for composites obtained at different sintering temperatures. The average pore size of the composites sintered at temperature $1400{ }^{\circ} \mathrm{C}$ increases with the growing volume fraction of aluminum hydroxide in the initial mixture (Fig. 3.6). In this case, the type of aluminum hydroxide used in the initial mixture exerts almost no effect on the average pore size. An increase in the average pore size is also observed for the composites sintered at $1500{ }^{\circ} \mathrm{C}$, though only for those made from the $\mathrm{CD}$ zirconia powder. The average pore size of the PCS zirconia powder composites does not change (Fig. 3.c). Similarly, the average pore size of all composites sintered at $1650{ }^{\circ} \mathrm{C}$ does not vary depending on the aluminum hydroxide volume fraction (Fig. 3.d).

Analysis of the phase composition of the obtained ceramics shows that independently of the content of aluminum hydroxide in the initial mixture and its production method the sintering temperature growth is accompanied by a decrease of the tetragonal zirconia phase content in the porous 


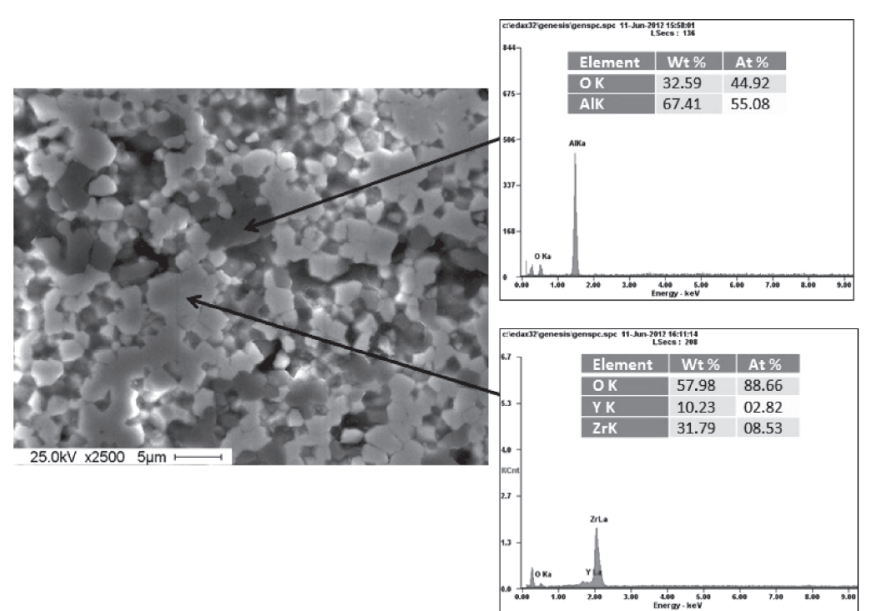

a)

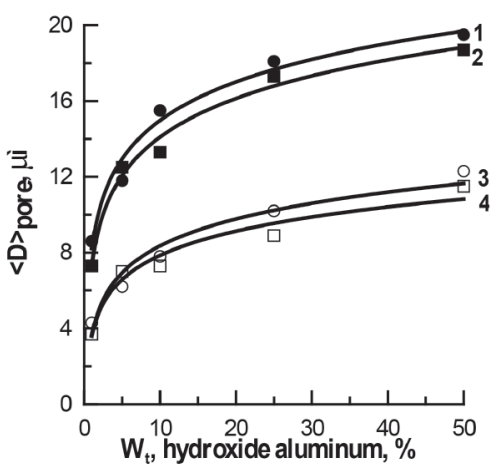

b)

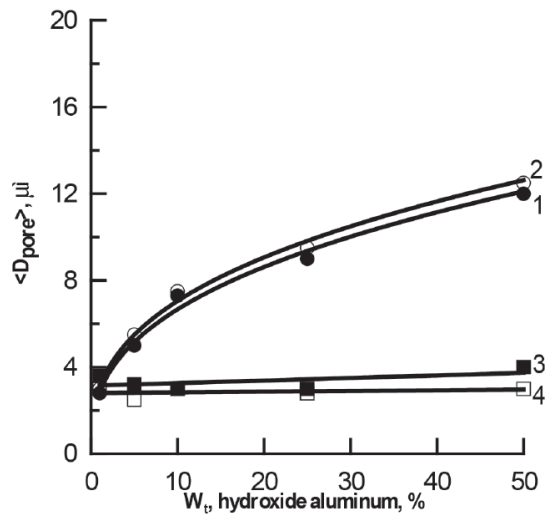

c)

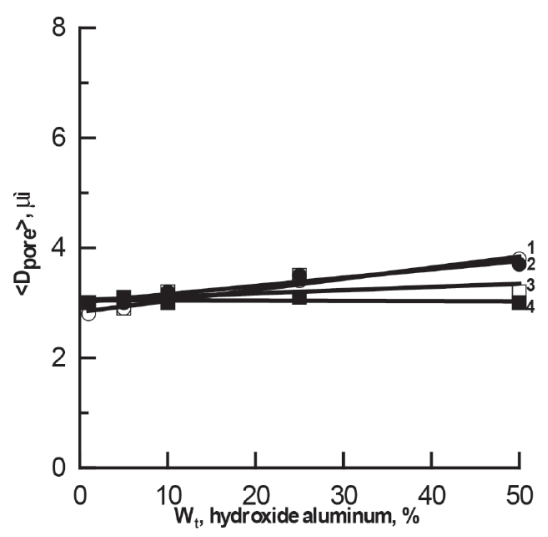

d)

Fig. 3. SEM image of the ceramics structure, elemental analysis data, and the pore size dependence of the aluminum hydroxide content. Aluminum hydroxide dependence corresponds to powder mixtures: $1-1 \% ; 2-5 \% ; 3-10 \%$; $4-25 \%$; $5-50 \%$

3. ábra Kerámiaszerkezet elektronmikroszkópos képe, elemanalizis eredményei és a pórusméret függése az alumínium-hidroxid tartalomtól. Alumínium-hidroxid tartalmak: 1 - 1 \%; $2-5 \% ; 3-10 \% ; 4-25 \% ; 5-50 \%$

$\mathrm{ZrO}_{2}-\mathrm{Al}_{2} \mathrm{O}_{3}$ composites. In the sintering temperature range $1400-1550{ }^{\circ} \mathrm{C}$ of the composites the tetragonal zirconia phase content decreases from 70 to $25 \%$ and does not change up to a sintering temperature of $1650{ }^{\circ} \mathrm{C}$. In the $\mathrm{PCS} \mathrm{ZrO}_{2}(\mathrm{Y})$ powder composites with 1,5 and $10 \mathrm{~m} \%$ of aluminum hydroxide in the initial mixture, independently of its production method, the tetragonal $\mathrm{ZrO}_{2}$ phase content remains at $90 \%$ up to a sintering temperature of $1600{ }^{\circ} \mathrm{C}$. For the ceramics with 25 and $50 \%$ $\mathrm{Al}_{2} \mathrm{O}_{3} \times 4 \mathrm{H}_{2} \mathrm{O}$ in the initial mixture the tetragonal $\mathrm{ZrO}_{2}$ phase content decreases from 90 to $40 \%$ at sintering temperatures 1500 and $1650{ }^{\circ} \mathrm{C}$, respectively. For the composites with 25 and $50 \% \mathrm{Al}(\mathrm{OH})_{3}$ in the initial mixture the tetragonal $\mathrm{ZrO}_{2}$ phase content decreases to $50 \%$ at sintering temperature $1500{ }^{\circ} \mathrm{C}$ and higher. At sintering temperature $1400{ }^{\circ} \mathrm{C}$, independently of the aluminum hydroxide content in the initial mixture and its production method, the tetragonal zirconia phase content in the $\mathrm{ZrO}_{2}-\mathrm{Al}_{2} \mathrm{O}_{3}$ composites made from the PCS $\mathrm{ZrO}_{2}\left(\mathrm{Y}_{2} \mathrm{O}_{3}\right)$ powder is $100 \%$. It is known [1, 3 ,4] that there is the notion of the critical grain size for the tetragonal modification of zirconia at which the tetragonalto-monoclinic transformation takes place; this value is equal to $1.2 \mu \mathrm{m}$. The correlation between the zirconia grain size and its tetragonal phase content in the composites shows that in the CD powder ceramics the tetragonal zirconia phase content rapidly decreases in the average grain size interval from 0.4 to $0.8 \mu \mathrm{m}$. As for the PCS powder composites, the most rapid decrease in the tetragonal $\mathrm{ZrO}_{2}$ phase content is observed at an average grain size ranging from 0.6 to $0.8 \mu \mathrm{m}$. It is also known [5] that the critical grain size of the tetragonal modification of zirconia can decrease with porosity growth in the material. This is related to a decrease in the level of the elastic stresses induced by neighboring grains and suppressing the tetragonalto-monoclinic transformation occurring with an increase of the unit cell volume. The porosity of the studied ceramics varied from 10 to $60 \%$, due to which, probably, the value of the critical grain size in them was lower as compared to $[3,4]$. It is also probable that, along with the $\mathrm{ZrO}_{2}$ grain size, the presence of $\mathrm{Al}_{2} \mathrm{O}_{3}$ could also influence the ratio of the tetragonal and monoclinic $\mathrm{ZrO}_{2}$ phases in the $\mathrm{ZrO}_{2}-\mathrm{Al}_{2} \mathrm{O}_{3}$ composites. As has been shown above, for the $\mathrm{ZrO}_{2}(\mathrm{Y})$ powder composites with 25 and $50 \%$ of aluminum hydroxide in the initial mixture, which respectively corresponds to 21 and $42 \%$ of $\mathrm{Al}_{2} \mathrm{O}_{3}$ in the sintered ceramics, the tetragonal zirconia phase content decreases drastically at sintering temperature above $1500{ }^{\circ} \mathrm{C}$. This effect can also be caused by the formation of the chemical compound $\mathrm{Y}_{3} \mathrm{Al}_{5} \mathrm{O}_{12}$, or yttrium aluminum garnet. As is shown in [6], independently of the mixture composition, the interaction of yttria and alumina begins at temperature $900-950{ }^{\circ} \mathrm{C}$ with the formation of the $\mathrm{Y}_{4} \mathrm{Al}_{2} \mathrm{O}_{9}$ compound, $\mathrm{YAlO}_{3}$ is formed at 1100 ${ }^{\circ} \mathrm{C}$, and starting from $1300{ }^{\circ} \mathrm{C}$ the yttrium aluminum garnet $\mathrm{Y}_{3} \mathrm{Al}_{5} \mathrm{O}_{12}$ is crystallized. So, a stable $\mathrm{Y}_{3} \mathrm{Al}_{5} \mathrm{O}_{12}$ compound can be formed in the $\mathrm{Y}_{2} \mathrm{O}_{3}-\mathrm{Al}_{2} \mathrm{O}_{3}$ system at temperature above 
$1300{ }^{\circ} \mathrm{C}$ independently of the mixture composition $[6,7]$. Apparently, the formation of yttrium aluminum garnet in the $\mathrm{ZrO}_{2}-\mathrm{Al}_{2} \mathrm{O}_{3}$ composite materials could lead to destabilization of the tetragonal zirconia phase. However, the $\mathrm{X}$-ray diffraction patterns of the $\mathrm{ZrO}_{2}-\mathrm{Al}_{2} \mathrm{O}_{3}$ composites had no reflections from $\mathrm{Y}_{3} \mathrm{Al}_{5} \mathrm{O}_{12}$ owing to a small amount of yttria in the system.

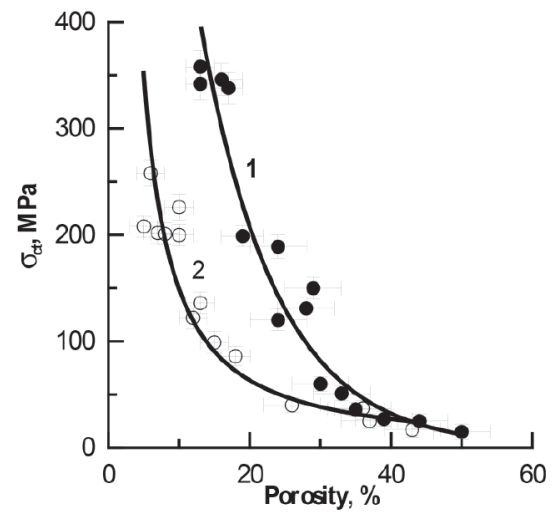

Fig. 4. Dependence of porosity on the crystallite size of the tetragonal zirconia phase in composite powders on the basis of different zirconia. Dependence corresponds to ceramics based on zirconia powders: $1-C D ; 2-P C S$

4. ábra A tetragonális cirkónium-oxid fázis porozitása és a krisztallit méret között összefüggés különböző cirkónium-oxid kompozit porokban. Jelmagyarázat: 1 - CD; 2- PCS

Fig. 4 illustrates the dependence between porosity of $\mathrm{ZrO}_{2}-$ $\mathrm{Al}_{2} \mathrm{O}_{3}$ composites and the size of coherent diffracting domains of the tetragonal zirconia phase. It is evident from the figure that with the size reduction of coherent diffracting domains of the tetragonal $\mathrm{ZrO}_{2}$ phase, the porosity of the composites decreases. Extrapolating the approximation function to the non-porous state gives the size of the coherent diffracting domains of the tetragonal $\mathrm{ZrO}_{2}$ phase equal to $65 \mathrm{~nm}$ for the CD zirconia powder composites, and $20 \mathrm{~nm}$ for the PCS zirconia powder composites.

Fig. 5 illustrates the porosity dependence of the tensile strength of the $\mathrm{ZrO}_{2}-\mathrm{Al}_{2} \mathrm{O}_{3}$ composites. The PCS zirconia powder composites have the highest tensile strength $1100 \mathrm{MPa}$ at $7 \%$ porosity (Fig. 5.a). For the CD zirconia powder composites, the highest tensile strength is $350 \mathrm{MPa}$ at $20 \%$ porosity (Fig. 5.b). As is seen from Fig. 5, the dependences are exponential. Extrapolation to the non-porous state gives the

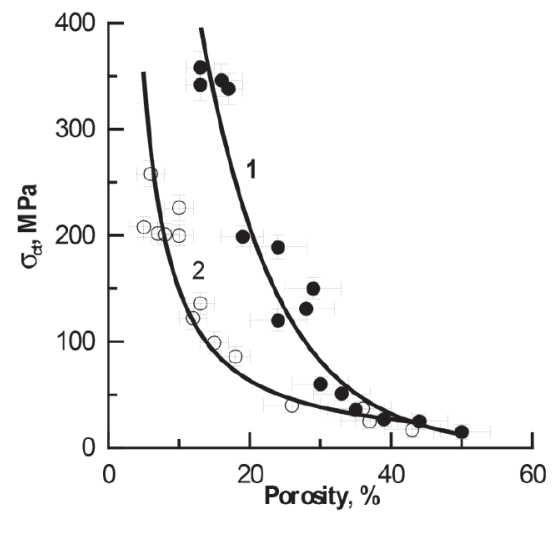

tensile strength values equal to $1300-2400 \mathrm{MPa}$, which is in agreement with the data provided in $[1,8,9]$. It is remarkable that the type of aluminum hydroxide used in the initial powder mixture had no effect on the strength of the $\mathrm{ZrO}_{2}-\mathrm{Al}_{2} \mathrm{O}_{3}$ ceramics made from the PCS $\mathrm{ZrO}_{2}\left(\mathrm{Y}_{2} \mathrm{O}_{3}\right)$ powder. Contrarily, the tensile strength of the $\mathrm{CD} \mathrm{ZrO}_{2}\left(\mathrm{Y}_{2} \mathrm{O}_{3}\right)$ powder composites was higher in composites whose initial powder mixture contained $\mathrm{Al}_{2} \mathrm{O}_{3} \times 4 \mathrm{H}_{2} \mathrm{O}$.

\section{Conclusions}

1. The critical grain size of the tetragonal modification of $\mathrm{ZrO}_{2}$ in porous $\mathrm{ZrO}_{2}-\mathrm{Al}_{2} \mathrm{O}_{3}$ ceramics is found to be $0.8 \mu \mathrm{m}$, in contrast to $1.2 \mu \mathrm{m}$ for non-porous $\mathrm{ZrO}_{2}$.

2. The sintering temperature determines the average pore size in the composites. An increase in the aluminum hydroxide content at low sintering temperatures causes a significant (more than threefold) growth of the average pore size, while at temperature growth the pore size is independent of the aluminum hydroxide content. As for the PCS zirconia powder composites, this effect is observed at lower temperatures.

3. The strength of the $\mathrm{ZrO}_{2}-\mathrm{Al}_{2} \mathrm{O}_{3}$ composites made from the PCS $\mathrm{ZrO}_{2}$ powder is higher than the strength of the $\mathrm{CD}$ $\mathrm{ZrO}_{2}$ powder composites; it is independent of the type of aluminum hydroxide in the initial mixture. The strength of the $\mathrm{ZrO}_{2}-\mathrm{Al}_{2} \mathrm{O}_{3}$ composites made from the $\mathrm{CD} \mathrm{ZrO}_{2}$ powder does depend on the type of aluminum hydroxide: the composites on the basis of the zirconia - hydrated alumina powder mixture have higher strength than the composites on the basis of the zirconia - bayerite powder mixture.

4. The crystallite size of the tetragonal zirconia phase determines the sintered material porosity: for the PCS zirconia powder composites the non-porous state is attained at the average crystallite size of the tetragonal $\mathrm{ZrO}_{2}$ phase equal to $20 \mathrm{~nm}$, and for the CD zirconia powder composites it is about $65 \mathrm{~nm}$.

\section{Acknowledgements}

This work has received partial financial support by Tomsk State University Competitiveness Improvement Program and RF President Grant MK-5681.2014.8.

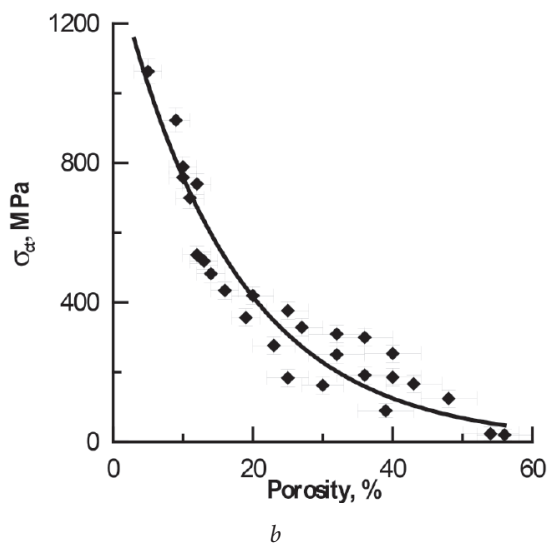

Fig. 5. Tensile strength - porosity dependence for ceramics on the basis of zirconia powder: (a) - CD, (b) - PCS. Dependence corresponds to ceramics based on hydroxide powders: 1 $\mathrm{Al}_{2} \mathrm{O}_{3} \times 4 \mathrm{H}_{2} \mathrm{O} ; 2-\mathrm{Al}(\mathrm{OH})_{3}$

5. ábra Húzószilárdság és porozitás összefüggése különbözö cirkónium-oxid kompozit porokban. (a) - CD, (b) - PCS. Jelmagyarázat a CD porokhoz: $\left.1-\mathrm{Al}_{2} \mathrm{O}_{3} \times 4 \mathrm{H}_{2} \mathrm{O} ; 2-\mathrm{Al}_{(\mathrm{OH}}\right)_{3}$ 


\section{References}

[1] Wang, J. - Stevens, R. (1989): Zirconia-toughened alumina (ZTA) ceramics. Journal of Materials Science. Vol. 24, No. 10, pp. 3421-3440. http://dx.doi.org/10.1007/BF02385721

[2] Lukin, E. S. - Makarov, N. A. - Dodonova, I. V. - Tarasova, S. V. - Badina, E. A. - Popova, N. A. (2001): New ceramic materials based on aluminum oxide. Refractories and Industrial Ceramics. Vol. 42, No. 7, pp. 261-268. http://dx.doi.org/10.1023/A:1012758727396

[3] Ingel, R. P. - Lewis, D. (1986): Lattice parameters and density for $\mathrm{Y}_{2} \mathrm{O}_{3}$ stabilized $\mathrm{ZrO}_{2}$. Journal of the American Ceramic Society. Vol. 69, No. 4, pp. 325-332. http://dx.doi.org/10.1111/j.1151-2916.1986.tb04741.x

[4] Tsubakino, H. - Sonoda, K. - Nozato, R. (1993): Martensite transformation behaviour during isothermal ageing in partially stabilized zirconia with and without alumina addition. Journal of Materials Science Letters. Vol. 12, No. 3, pp. 196-198. http://dx.doi.org/10.1007/BF00819957

[5] Piconi, C. - Maccauro, G. (1999): Review: Zirconia as a ceramic biomaterial. Biomaterials. Vol. 20, No. 1, pp. 1-25. http://dx.doi.org/10.1016/S0142-9612(98)00010-6

[6] Waku, Y. - Sakata, S. - Mitanni, A. - Shimizu, K. (2002): Temperature dependence of flexural strength and microstructure of $\mathrm{Al}_{2} \mathrm{O}_{3} / \mathrm{Y}_{3} \mathrm{Al}_{5} \mathrm{O}_{12} /$ $\mathrm{ZrO}_{2}$ ternary melt growth composites. Journal of Materials Science. Vol. 37, No. 14, pp. 2975-2982. http://dx.doi.org/10.1023/A:1016073115264

[7] Kibbel, B. W. - Heuer, A. H. (1984): Ripening of inter- and intragranular $\mathrm{ZrO}_{2}$ particles in $\mathrm{ZrO}_{2}$-toughened $\mathrm{Al}_{2} \mathrm{O}_{3}$. Science and Technology of Zirconia II, Advances in Ceramics, Vol. 12, Ed. by Rühle, M., Claussen, N., and Heuer, A. H., 1984, pp. 415-424.

[8] Gömze, A. L. (2013): 2nd International Conference on Competitive Materials and Technological Processes (IC-CMTP2), IOP Conference Series: Materials Science and Engineering, IOP Publishing, 2013, Vol. 47, No. 1.
[9] Kulkov, S. N. - Buyakova, S. P. - Smolin, A. Y. - Roman, N. V. Kinelovskii, S. A. (2011): Percolation transitions in porous structure and their effect on physicochemical properties of ceramics. Technical Physics Letters. Vol. 37, No. 4, pp. 360-363.

http://dx.doi.org/10.1134/S106378501104020

Ref.:

Zhukov, I. - Buyakova, Svetlana P. - Kulkov, Sergei S.: Properties of $\mathrm{ZrO}_{2}-\mathrm{Al}_{2} \mathrm{O}_{3}$ ceramics produced from different powder mixtures of zirconia and aluminum hydroxide

Építőanyag - Journal of Silicate Based and Composite Materials, Vol. 68, No. 3 (2016), 74-78. p.

http://dx.doi.org/10.14382/epitoanyag-jsbcm.2016.13

Különböző összetételű cirkónium- és alumínium-

hidroxid keverékekből szintetizált $\mathrm{ZrO}_{2}-\mathrm{Al}_{2} \mathrm{O}_{3}$ kerámiák tulajdonságai

A cikk különféle eljárásokkal elôállított $\mathrm{ZrO}_{2}-\mathrm{Al}_{2} \mathrm{O}_{3}$ porózus porkerámiák tulajdonságait ismerteti. A vizsgált területek felölelik többek között a szerkezet, a fázisösszetétel, a kristályszerkezet és a szilárdság kérdéseit. Az eredmények rávilágítanak, hogy a szinterelt $\mathrm{ZrO}_{2}-\mathrm{Al}_{2} \mathrm{O}_{3}$ porózus porkerámiák szilárdsága függ attól, hogy milyen típusú alumínium-hidroxidot tartalmaz a kezdeti keverék. A szinterelés hômérséklete meghatározza a porkerámiák porozitását.

Kulcsszavak: $\mathrm{ZrO}_{2}-\mathrm{Al}_{2} \mathrm{O}_{3}$ kompozitok, szinterelés, szilárdság, krisztallit méret

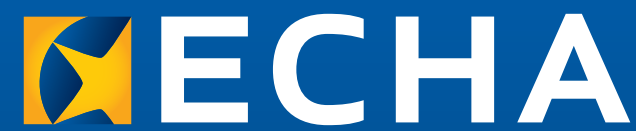

EUROPEAN CHEMICALS AGENCY

\title{
The European Chemicals Agency
}

The European Chemicals Agency (ECHA) is the driving force among regulatory authorities in implementing the EU's groundbreaking chemicals legislation for the benefit of human health and the environment as well as for innovation and competitiveness. ECHA helps companies to comply with the legislation, advances the safe use of chemicals, provides information on chemicals and addresses chemicals of concern.

\section{echa.europa.eu}

\author{
EUROPEAN CHEMICALS AGENCY \\ ANNANKATU 18, P. O. BOX 400, \\ FI - 00121 HELSINKI, FINLAND \\ PHONE +358-9-686180
}

